\title{
A Pre-Experimental Study on a Process-Genre Approach for Teaching Essay Writing
}

\author{
Wagdi Rashad Ali Bin-Hady ${ }^{1}$, Aref Nassi Abdu Nasser², Abdu T. Al-Kadi ${ }^{3,4}$ \\ ${ }^{1}$ Hadhrmout University \\ ${ }^{2}$ Abyan University \\ ${ }^{3}$ Ibb University \\ ${ }^{4}$ University of Science \& Technology
}

\begin{abstract}
Correspondence concerning this article should be addressed to Wagdi Bin-Hady, Hadhrmout University, PO Box 50512, Mukalla, Hadhramaut, Yemen. Email: wagdyrashad@gmail.com
\end{abstract}

\begin{abstract}
This study explored the feasibility of using a process-genre approach (PGA) for teaching academic writing from the perspective of EFL undergraduates. The sample consisted of 15 students enrolled in a four-year English program at the College of Education in Socotra, Yemen during the academic year 2018-2019. The study followed a pre-experimental design in which a pretest was given to the sample, and an extensive 30-hours program was pursued using the PGA. Additionally, ten informants were singled out for interviews to explore their opinions about the PGA-based teaching they experienced during the experiment. A Wilcoxon Signed Rank Test was used to calculate the degree of significance in students' improvement on opinion essay writing $(Z=3.408, p<0.05)$ between the pretest and posttest in favor of the latter. The findings also revealed that students had positive perceptions towards the PGA that was applied by their instructors. The findings suggest that applying such an approach in writing courses could engage learners in writing practices that they view positively.
\end{abstract}

Keywords: academic writing, EFL learners, opinion essay, process-genre approach, socotra

\section{Introduction}

One of the goals EFL learners aim to achieve is the mastering of academic writing to express themselves proficiently. A well-written text can be a challenging endeavor, not only for second language (L2) learners but also for native speakers. Even contributors to scholarly journals and academic gatherings such as conferences and symposiums subject their papers to peer review to get insights on their writing. This is partially owing to the complex nature of the writing process. In L2 contexts, learners exert efforts to write essays effectively, yet they encounter different problems that limit their writing abilities (Brooks, 2017; Gilmore, 2009; Hyland, 2002; Yuvaypan \& Rathert, 2018). In academia, several approaches have been suggested to enhance writing skills. The Process-Genre Approach (hereafter PGA) is one of the prominent approaches in English Language Teaching (ELT). It surfaced as an advantage over the preceding approaches - product approach and the process approach. The product approach, rooted in audio-lingual teaching as an instructor-centered approach, highlights practicing syntactical and rhetorical drills. It views writing as an imitation of certain patterns without an emphasis on the process of writing (Rusinovci, 2015). Later on, concerns about how a text is written became the theme for the process approach. Again, this approach was unsatisfactory for many ELT experts, educators, and researchers (Ajmal, 2005; Arici \& Kaldirim, 2015; Raimes, 1983, as cited in Zhang, 2018, Rusinovci, 2017). Another approach (the genre approach) emerged. It lays heavy emphasis on the social context in which writing is produced (Badger \& White, 2000). With the passage of time, communicative language teaching paved the way for a more comprehensive approach - the process-genre approach (PGA), which is the thrust of the current study.

It is quite uncontroversial now that the PGA is advantageous over other approaches. It has been widely fostered and it is now flourishing in the field of ELT. Prior to the PGA, many writing instructors intensified their attention on the content of their students' writing, not on the organization of the academic writing process 
(Furneaux, 1995). Brooks (2013) affirmed that instructors should focus not only on the sentence level, but also on the use of rhetorical and discourse skills if they wish to enhance their students' writing skills. Viewing writing as a communicative task (Badger \& White, 2000), using the PGA for teaching academic writing has been

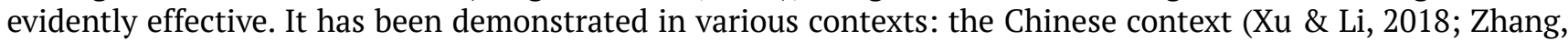
2018), Colombia (Arteaga Lara, 2017), Pakistan (Ajmal, 2015), Nigeria (Saputra \& Marzulina, 2015), and Indonesia (Eliwarti \& Maarof, 2017; Ghufron, 2016), and the present study falls within this landscape of research. In the Arab EFL context, the PGA is largely underrepresented in the body of literature (Assaggaf, 2016). Drawing on Hyland's (2002) and other previous research on the PGA, the study at hand intends to provide more evidence for the viability of this approach from an Arab EFL context. The researchers who conducted this study have taught academic writing at the undergraduate level for years using a variety of approaches; and thus they can add their PGA-based writing experience to the investigation.

This attempt addresses the cogency of the PGA in the domain of English for academic purposes at the College of Education on the island of Socotra, Yemen. More pointedly, the present endeavor addresses the following questions:

1. Is a process-genre approach conducive to improving students' EFL academic essay writing?

2. What are the students' perceptions towards a PGA-based academic writing course?

These two questions were used as a point of departure to delineate the significance of the PGA for university students' writing abilities. Besides many other factors, adopting an appropriate teaching approach such as the approach under scrutiny is vital for developing writing syllabi in the EFL program where this study was conducted.

\section{Literature Review}

The PGA has gained prominence as an approach subsumed into communicative language teaching, the widely accepted paradigm for teaching an L2. This approach, proposed by Badger and White (2000) is about writing as a communicative activity. Reporting positive perceptions of students and instructors on the PGA in academic writing, numerous studies recommended employing it in writing classes (Ajmal, 2015; Assaggaf, 2016; Eliwarti \& Maarof, 2017; Ghufron, 2016). The essence of this approach according to Ghufron (2016) is that it empowers writers to experience every stage of the writing process: prewriting, drafting, and revising in order to deliver messages accurately. As its name suggests, the process-genre approach is a combination of two approaches: the process approach and the genre approach. As the concept articulates, the process-genre approach utilizes the advantages of both the process approach such as planning, editing, and publishing and the properties of the genre approach, i.e. using the language for communication purposes and according to the situation (Assaggaf, 2016; Eliwarti \& Maarof, 2017; Saputra \& Marzulina, 2015).

The approach in focus involves six criteria that guide students in essay writing. These criteria, according to Refnaldi (2013), include (a) the incipient knowledge to enlarge a paragraph into an essay, (b) writing an introductory paragraph with a hook, (c) background information and creating a thesis sentence, (d) developing the body paragraphs with their elements, (e) topic sentences, (f) and writing a conclusion for the essay. However, these criteria represent the basic elements for maintaining the generic structure of the text. In this respect, these criteria stand for the genre-related part of the hybrid approach, i.e. the GPA. Pertaining to the processrelated part, emphasis is given to several processes and strategies starting with generating ideas and ending with revising strategies as encapsulated in Figure 1. 


\section{Figure 1}

The PGA model adopted by Refnaldi

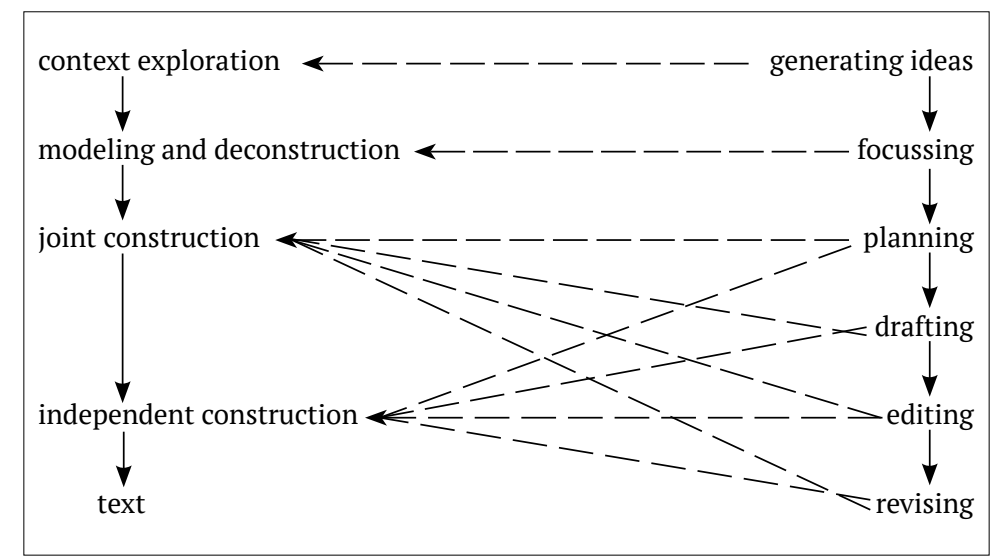

Note. Adopted from " The process-genre based model for teaching essay writing", by Refnaldi 2013, Proceeding of the International Seminar on Languages and Arts, vol. 2, pp. 483. Copyright 2013 by FBS Universitas Negeri Padang.

As can be seen in Figure 1 above, a text is constructed through different strategies and processes. These strategies are represented as generating ideas, focusing, planning, drafting, editing, and revising. Furthermore, these strategies are employed in different stages including context exploration, modeling, joint construction, and independent construction through which texts are constructed. In the process approach, "the instructor primarily facilitates the learners' writing, and providing input or stimulus is considered to be less important. Like babies and young children who develop, rather than learn, their mother-tongue, second language learners develop, rather than consciously learn, writing skills. Instructors draw out the learners' potential” (Badger \& White, 2000, p.154). According to Badger and White, the instructor, learners, and texts are interconnected throughout the writing process. As Figure 2 illustrates, these three elements are involved from start to finish, and this overlapping/interconnectedness is what gives the approach prominence in the field of academic writing.

\section{Figure 2}

Badger \& White's Model of the PGA

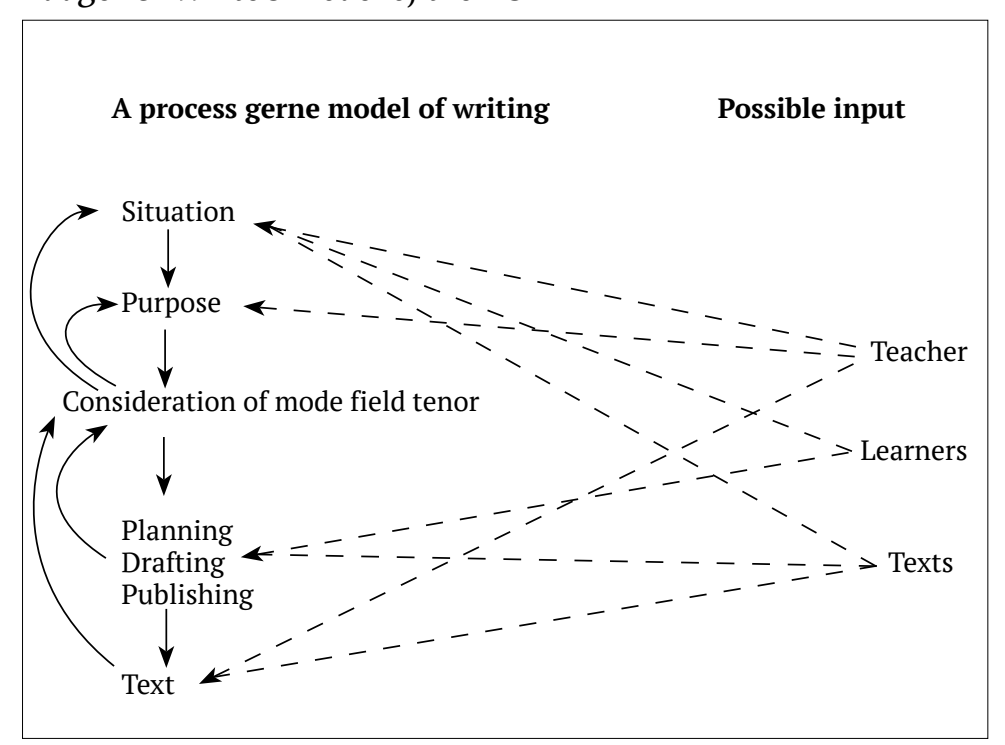

Note. Adopted from "A process genre approach to teaching writing", by R. Badger and G. White, G., 2000, ELT Journal, 45(2), 153 (http://doi.org/10.1093/elt/54.2.153). Copyright 2000 by ELT Journal. 
The PGA has been examined in different contexts. For example, Arteaga Lara (2017) examined the efficiency of the PGA in the Colombian context taking in data from thirteen learners in a bilingual school. The study showed that the PGA helped most of the participants to write well-structured paragraphs; it enabled them to develop an idea and then write on it without deviation from the subject. In the Chinese context, Zhang (2018) studied learners' academic writing using the PGA, recruiting 59 graduates in a Chinese university. A teaching experiment of 14 weeks was designed to test the effectiveness of this approach. The results showed a notable improvement in writing performance. In another research project from China, $\mathrm{Xu}$ and $\mathrm{Li}$ (2018) conducted action research to examine PGA feasibility for EAP at the doctorate level. This approach, which the authors considered a Western writing convention, helped Chinese EFL learners employ various writing strategies even in an advanced EFL program. In a similar vein, Ghufron (2016) unearthed the usefulness of the PGA in teaching writing, linking it to students' self-esteem. The results of the writing test and questionnaire on self-esteem showed that the PGA was more effective than the product approach, and students with high self-esteem, who were taught by the PGA, had better writing results. More and more results on the usefulness of the PGA are being reported. Quite recently, Alabere and Shapii (2019) explored the value of the PGA in the Malaysian ESL context. The results of pretest-posttest exhibited the outperformance of the experimental group over the control group taught with a traditional (product) method. Prior to the experiment, both groups were homogeneous and performance differences at the end of the intervention were contributable to the efficiency of the PGA. Furthermore, Assaggaf (2016) focused on the PGA in the teaching of English report writing in a computer science department in Yemen. Recruiting 17 students, the study examined the implementation of report writing in five dimensions: form, genre, planning, drafting, and revising. The findings revealed students' positive views on the teaching of academic writing using the PGA. Building on prior research on the PGA, the present study attempts to provide evidence for its value for developing EFL students' academic writing skills. It ascertains that the PGA is viable for Yemeni EFL students' achievement in composing opinion essays through (a) assessing the impact of an EFL program using the PGA on students' writing, and (b) students' perceptions towards an EFL teaching program incorporating the PGA. The study juxtaposed perceptions with experimental data to strengthen the investigation.

\section{Methodology}

\section{Sample}

The sample consisted of 15 senior students enrolled in the Department of English, Faculty of Education, Hadhramout University on the island of Socotra, during the academic year 2018-2019. The sample comprised all the fourth-year male and female students of English. They were socio-linguistically homogeneous with an average age of 22 . At the beginning of the semester, the instructor asked for the students' informed consent regarding their participation in the study. They all agreed to participate in the research and ten of them were chosen randomly to be interviewed. The researcher explained to them the aims of the study, and the research process beginning from the pretest to the treatment, the posttest, and finally the interview. They were also told that their identity would remain anonymous and their information would be kept confidential. During their EFL course of study, this cohort of learners performed several language activities including writing tasks as an essential part of the program. By the end of the PGA-based teaching, ten informants were singled out for interviews to explore their opinions about their experiences.

\section{Design}

The inquiry adopted a pre-experimental research design in which a single group of participants was observed after a treatment presumed to cause change. In the experiment, the participants underwent a 30-hour PGAbased teaching program. The experiment continued for ten weeks (three hours a week). Toward the program closure, a posttest was administered to measure students' abilities in essay writing. A particular focus was on elements of content and organization.

\section{Instruments}

The study adopted two tools to collect the data from the sample. The first instrument was the writing test. The reliability of the test was calculated using the Spearman-Brown Coefficient. The items were split into two 
halves. The coefficient between the criteria reached .88, which is strong correlation value. At the beginning of the semester, the instructor gave the students a writing task (a pretest) to write about their opinion on living in the countryside and cities (see Appendix 1). In opinion essays, there are always two contradictory opinions for each topic presented to write about. Students should select one opinion they agreed and try to defend their opinion by providing some facts to persuade the readers. Moreover, they should also think of the counter opinion and try to minimize its importance to the readers.

The assignments were sent to another rater who had been in charge of the same academic writing course for five years. The instructor asked the rater to send his assessments on the students' pretest essays. At the end of the semester, the students were asked to write on the influence of the internet on students (see Appendix 2).

The second instrument was an unstructured interview to collect information on students' opinions regarding the academic writing course in general as well as writing through the PGA that the instructor used during the semester. Ten students were interviewed at the end of the PGA-based teaching program. The interviews were conducted by the course instructor. As they were in their last year of study, the students' levels of English were good enough to express their opinions, except few terms that required Arabic-English oral translation during the interview. Responses were audio-recorded. In the analysis, each interviewee was given a number for confidentiality- to avoid using their real names. Coding was used for transcribing the recordings from one to ten. All ten transcriptions were analyzed, but only four of them were quoted to represent the whole sample in the presentation of the data analysis because the other interviews reflected similar positive attitudes toward the academic writing course they experienced for ten weeks.

\section{Classroom Procedures}

The researchers followed certain steps for teaching essays to the undergraduates. The steps are similar to the model suggested by Refnaldi (2013) and include the following steps:

(a) extensive lectures about the elements of paragraphs/essays,

(b) extensive lectures about genres (essay types and their aim or purpose),

(c) reading essays of the same genre and analyzing them,

(d) practicing some of the linguistic areas used in the essay, grammar, and vocabulary,

(e) training students on brainstorming and practicing it in the classroom,

(f) providing the class with an outline of a specific genre,

(g) giving them the elements and purpose of each part in the online - creating a real situation and motiving students to start off writing about it in a group of three students (starting by brainstorming, outlining, drafting).

The instructor guided the students throughout the process, facilitating the writing tasks and finally providing feedback. Students usually developed their essay working in groups depending on the essay type. For example, the second chapter of the course was on descriptive essays, so after becoming familiar with the writing process, they were prompted to write a three-paragraph essay describing the classroom they were studying in by following the given steps based on format guidelines to check their essay elements and another model for peer feedback. At the end of the lecture, the instructor gave them an assignment to go home and write a threeparagraph descriptive essay on a famous tourist place on their island that tourists usually visit and to submit their writing to their peers for feedback and finally to the instructor for final corrective feedback. This included preparation, modelling and reinforcing, planning, joint constructing, independent constructing, and revising. After assessing the students' essays according to the criteria below, the data were processed to identify statistically significant differences in essay writing performance between the pretest and posttest.

\section{Data Analysis}

Adopting Brooks' (2017) benchmark, this study analyzed students' essays with relevance to (a) paragraph structure, (b) location of the main idea, (c) presence or absence of support for the main idea, and (d) internal coherence of the composition. A rubric was used to assess the students' performance on the pretest and the posttest. This rubric was adapted from Savage and Mayer (2012). A scale from 1 into 10 was used to assess the students' writing in each of the seven criteria. It focused on the following criteria:

Criterion 1 (C.1): Stating a clear position in the thesis statement 
Criterion 2 (C.2): Stating a clear topic sentence and support for the body paragraphs

Criterion 3 (C.3): Using facts to support opinions

Criterion 4 (C.4): Providing a counter-argument and refutation

Criterion 5 (C.5): Providing a conclusion with convincing suggestions, a prediction, or a warning

Criterion 6 (C.6): Expressing quantifiers for avoiding generalizations

Criterion 7 (C.7): Using connectors

For each of these criteria, the students' performance was scored and the total mark was calculated along with the arithmetic mean of each student's performance. The mean values of the students' performance were calculated. The range between these arithmetic means was also calculated to assess the students' performance with regard to using the PGA in the teaching of academic writing pertaining to the elements determined in the criteria of the above-mentioned rubric. Because of the small size of the sample, the non-parametric test of Wilcoxon Signed Rank Test was used. The data results from the interviews were also analyzed qualitatively.

\section{Results}

The results are arranged in two parts. The first part corresponds to the first research question. It verifies statistically significant differences between the students' writing on the pretest and the posttest. The second part depicts data from interviews with the participants.

The pretest and posttest results demonstrate a benchmark for comparing and discussing the results. As the data in Table 1 displays, the performance of students in question improved. After scrutinizing the data, it can be seen that each student's performance, as represented by the arithmetic mean scores of the seven criteria, on the posttest was higher than their performance on the pretest. It can be seen that the general mean of the students' performance on the posttest was 7.46, which was higher than that on the pretest (4.53). Thus, the general mean of the range between the two means was 2.93 . Noticeably, the largest improvement in student performance was 6.15 , whereas the lowest was 0.26 .

Table 1

Participants' performance in the pretest and the posttest with range

\begin{tabular}{|c|c|c|c|}
\hline S. No. & $\begin{array}{l}\text { The mean of the students' } \\
\text { performance on the pretest }\end{array}$ & $\begin{array}{l}\text { The mean of the students' } \\
\text { performance on the posttest }\end{array}$ & Range \\
\hline Student 1 & 8.14 & 8.4 & 0.26 \\
\hline Student 2 & 5.28 & 6.57 & 1.29 \\
\hline Student 3 & 5.85 & 8.14 & 2.29 \\
\hline Student 4 & 3.42 & 7.42 & 4 \\
\hline Student 5 & 3.57 & 6 & 2.43 \\
\hline Student 6 & 1.85 & 7.42 & 5.57 \\
\hline Student 7 & 2.42 & 8.57 & 6.15 \\
\hline Student 8 & 3 & 5 & 2 \\
\hline Student 9 & 6.71 & 8.57 & 1.86 \\
\hline Student 10 & 4.85 & 7.14 & 2.29 \\
\hline Student 11 & 7.57 & 8.57 & 1 \\
\hline Student 12 & 2.14 & 7.57 & 5.43 \\
\hline Student 13 & 3.14 & 8 & 4.86 \\
\hline Student 14 & 2.28 & 6 & 3.72 \\
\hline Student 15 & 7.71 & 8.57 & 0.86 \\
\hline General mean & 4.53 & 7.46 & 2.93 \\
\hline
\end{tabular}


In order to ascertain the statistical difference between the pretest and posttest results, an additional statistical calculation was used. The Wilcoxon Signed Rank Test was used to calculate the mean scores for the pretest and posttest and the results are shown in Table 2. As the data in the table shows, the mean score of the posttest was higher than that of the pretest (31.7333 vs. 52.2667). Depending on the result of the Wilcoxon Signed Rank Test, there is a statistical difference between the pretest and the posttest. This significant difference in mean values indicates that students' writing improved at $\mathrm{Z}=-3.408$ and Sig. $=.001$.

Table 2

Wilcoxon Signed Rank Test

\begin{tabular}{|c|c|c|c|c|c|c|c|c|}
\hline & \multirow{2}{*}{$\mathbf{N}$} & \multirow{2}{*}{ Mean } & \multirow{2}{*}{ Std. Deviation } & \multicolumn{3}{|c|}{ Percentiles } & \multirow{2}{*}{$Z$ value } & \multirow{2}{*}{$\begin{array}{c}\text { Asymp. Sig } \\
\text { (2-tailed }\end{array}$} \\
\hline & & & & 25th & 50th (Median) & 75 th & & \\
\hline Pretest & 15 & 31.7333 & 15.46640 & 17.0000 & 25.0000 & 47.0000 & \multirow{2}{*}{$-3.408^{a}$} & \multirow{2}{*}{.001} \\
\hline Posttest & 15 & 52.2667 & 7.90539 & 46.0000 & 53.0000 & 60.0000 & & \\
\hline
\end{tabular}

Note.

a. Based on negative rank

Table 3 shows a comparison based on the students' performance on the pretest and the posttest across the criteria. As indicated in the table, the PGA for teaching academic writing was found to be effective for improving students' performance writing essays. The students' performance on the posttest was statistically higher, as indicated by (2-tailed Sig .018, p< 0.05), which is statistically significant for the students' performance on the posttest.

Table 3

Participants' performance on the pretest and posttest with the range across the criteria

\begin{tabular}{|c|c|c|c|c|}
\hline The criteria & 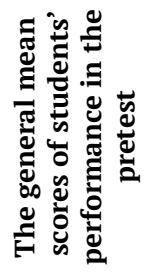 & 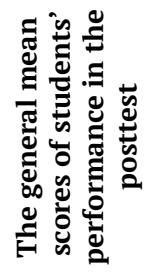 & 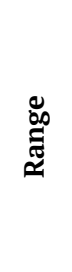 & 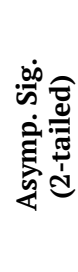 \\
\hline 1. Stating a clear position in the thesis statement & 6.4 & 7.8 & 1.4 & \\
\hline 2. Stating a clear topic sentence and support for body paragraphs & 5.53 & 8.13 & 2.6 & \\
\hline 3. Using facts to support opinions & 4.66 & 7.2 & 2.54 & \\
\hline 4. Providing a counter-argument and refutation & 3.2 & 7.6 & 4.4 & \\
\hline 5. Providing a conclusion with convincing suggestions, a prediction, or a warning & 4 & 7 & 3 & \\
\hline 6. Expressing quantifiers for avoiding generalizations & 3.26 & 7.26 & 4 & \\
\hline 7. Using connectors & 4.66 & 7.26 & 2.6 & \\
\hline Total & 4.5014 & 7.4643 & & .018 \\
\hline
\end{tabular}

The second part of the analysis is germane to students' perceptions towards a writing course that incorporated the PGA. After the course, the students were asked to share their perceptions. The responses were centered on two aspects: (a) students' perceptions towards academic writing in general, and (b) students' perceptions towards the instructor's teaching using the PGA. The results show that the students held a positive view towards academic writing as well as the teacher's instruction through the approach in question. The interviewees generally described the course as important and useful for developing their compositions. The extracts below clearly illustrate the interviewees' positive perceptions.

Participant 1:

In my opinion, academic writing is an important subject because it helps us to write freely about Participant 5: any topic the instructor chose. It gives us to learn and use the new vocabulary.

Our instructor gives us some elements of writing such as introduction, thesis statement, and conclusion. He teaches us step-by-step, and we get benefits in our writing. 
Participant 8:

The teaching practice is very enjoyable. The instructor makes it easy to understand through explaining and working in groups.

Participant 9:

In this course, I had a chance to write freely, step-by- step. I also collaborated with my classmates in writing the essay.

These quotations exemplify that the teaching practice using the PGA was engaging and amiable, reflecting students' confidence and enthusiasm. They also show that the learners had positive perceptions towards academic writing. Further analysis of the interviews revealed that the course that incorporated the PGA helped learners fix their writing mistakes and stimulated their motivation for writing. Taken together, the responses exhibited that academic writing based on the PGA had positive effects on their performance at different levels getting students to write freely, learning and using new vocabulary, and working collaboratively.

\section{Discussion}

The data analysis revealed the viability of using the process-genre approach for teaching academic writing. The results align with findings in the body of literature. For instance, Arteaga Lara (2017), Ajmal (2015), Eliwarti and Maarof (2017), Ghufron (2016), Luu (2011), Saputra and Marzulina (2015), Xu and Li (2018), Yuvaypan and Rathert (2018), and Zhang (2018) all hailed the PGA. In line with this body of prior research, the findings of the study at hand revealed that there was some improvement in students' writing under the auspices of the PGA. This is not surprising as previous studies came up with similar results. For instance, Ajmal (2015) confirmed that the PGA developed students' writing competence in the Pakistani context. Likewise, Gupitasar's (2013) study showed that the PGA developed students' competence writing application letters. Additionally, Alabere and Shapii (2019) reported that in an experimental study, the experimental group outperformed the control group owing to the PGA that the study centered on.

In the present study, however, the greatest improvement was in Criterion 4 . The data in Table 3 demonstrates that the highest degree of development in the students' performance was in providing a counter-argument and refutation where the mean difference between the pretest and the posttest was 4.4. On the contrary, the lowest improvements occurred in Criteria 1, i.e. stating a clear position in the thesis statement, which only increased by 1.4. This was followed by Criteria 2 and 3 (range values of 2.54 and 2.6). Because the thesis statement is the core element of an essay and all the other parts of the essay are directly related to it, students need more practice to acquire this ability before they embark to the main body of an essay. Criteria $5 \& 6$ also improved. Expressing quantifiers for avoiding generalizations was the second most improved criterion with a range of 4 . It can also be seen that the students' performance improved in terms of providing a conclusion with convincing suggestions, $a$ prediction, or a warning with a range of 3 . Overall, the students' improvement was lower for criteria 1, 2, 3, and 7 .

The second part of the analysis revolved around students' perceptions toward an academic writing course that fostered the approach under scrutiny. The respondents favored learning through the PGA and this validates teaching writing through this approach. These findings are similar to those explored by other researchers in the field, e.g. Assaggaf (2016), Eliwarti and Maarof (2017), who reported positive perceptions from both students and instructors. Likewise, Abdullah (2008) recommended instructors use the PGA for writing instruction as it helped students become independent writers. With regard to the teaching method - defined in this paper as approaching academic writing through the PGA- the interviewees' responses showed positive perceptions towards it. Some interviewees described PGA-based teaching as enjoyable and practical. Such a positive view could be attributable to some of the techniques this approach suggests: teaching writing through discussion, grouping (putting them in groups), and modelling (giving students models to follow). The cohort of learners who undertook the course experienced the difference between the PGA-based writing and the other traditional methods that were in use before the experiment.

Overall, students' perceptions and writing improvement are clear to see. The teaching intervention utilizing the PGA enhanced the participants' writing skills and adjusted their perceptions towards the process of writing that was previously touted as a 'vexing problem' and an unwelcome task. The findings suggest that the PGA instills valuable benefits. Using the PGA boosts learners' experience in the whole process from the beginning to 
the end of writing tasks. Considering the findings of the present study and similar results in the literature, it is quite reasonable to suggest adhering to this approach in writing classes as it helps students experience a variety of different writing tasks.

\section{Conclusion}

The study delved into using the process-genre approach for teaching essay writing at the collegiate level. Although the study was limited to a pre-experimental design with a limited number of informants, the findingsnot generalizable though- are vital to build on in further queries. They provide more evidence on the efficacy of the PGA that has been widely accepted in ESL and EFL contexts, and the context of the present study (Yemen) is not an exception. Taken together, the findings imply that learners should be trained on all of the steps of the PGA from start to finish. It is important thus to incorporate this approach when teaching writing to students studying English as a second or foreign language. The study had some limitations due to the research design. For one thing, the pre-experimental design by nature lacked a control group and thus failed to provide causeeffect results. It was also limited to opinion essay writing. Future research may explore other genres such as analytic writing, narrative writing, and the like. One more limitation is that the study attested to the significance of the approach from a trial on a small number of participants. Other researchers may include a larger sample and perhaps other research tools or may approach the effects of the PGA from a different viewpoint.

\section{References}

Abdullah, M. F. Y. (2008). A Process-genre approach in the improvement of academic writing for the undergraduates at Aden University [Unpublished doctoral dissertation]. EFL University.

Agibuay, R. M. (2017). Descriptive writing using the process-genre approach. Asia Pacific Journal of Contemporary Education and Communication Technology, 3(1), 272-282. https://apiar.org.au/wp-content/ uploads/2017/02/24_APJCECT_Feb_BRR7128_EDU-272-282.pdf

Ajmal, A. (2015). Process-genre approach to teaching writing university foundation course students in Pakistan. In The European Conference on Language Learning 2015 (pp. 351-356). The International Academic Forum.

Alabere R. \& Shapii, A (2019). The effects of process-genre approach on academic writing. Journal of English Education Society, 4(2), 47-52. https://org.doi:10.21070/jees.v4i2.2598

Arteaga Lara, H. M. (2017). Using the process-genre approach to improve fourth-grade EFL learners' paragraph writing. Latin American Journal of Content \& Language Integrated Learning, 10(2), 217-244. http://doi. org/10.5294/laclil.2017.10.2.3

Arici, A. F., \& Kaldirim, A. (2015). The effect of the process-based writing approach on writing success and anxiety of pre-service teachers. Anthropologist, 22(2), 318-327. http://doi.org/10.1080/09720073.2015.1189 1883

Assaggaf, H. T. (2016). A process genre approach to teaching report writing to Arab EFL computer science students. International Journal of English Linguistics, 6(6), 7-18. http://doi.org/10.5539/ijel.v6n6p8

Badger, R., \& White, G. (2000). A process genre approach to teaching writing. ELT Journal, 45(2), 153-160. http:// doi.org/10.1093/elt/54.2.153

Brooks, G. (2013). Assessment and Academic writing: A look at the use of rubrics in the second language writing classroom. Kwansei Gakuin University Humanities Review, 17, 227-240. http://hdl.handle.net/10236/10548

Brooks, G. (2017). Teaching Academic writing in content-based classes. In P. Clements, A. Krause, \& H. Brown (Eds.), Transformation in language education (pp. 1-5). JALT.

Eliwarti, \& Maarof, N. (2017). The Effect of process-genre approach on EFL students' writing performance. Applied Science and Technology, 1(1), 47-52. https://www.estech.org/index.php/IJSAT/article/view/9

Furneaux, C. (1995). The challenges of teaching academic writing. BBC English: Teachers' supplement. EAP

Ghufron, M. A. (2016). Process-genre approach, product approach, and students' self -esteem in teaching writing. Indonesian EFL Journal: Journal of ELT, Linguistics, and Literature, 2(1), 37-54. http://ejournal.kopertais4. or.id/index.php/efi

Gilmore, A. (2009). Using online corpora to develop students' writing skills. ELT Journal, 63(4), 363-372. http:// doi.org/10.1093/elt/ccn056 
Gupitasar, H. (2013). The implementation of process-genre approach to teaching writing business letter. Journal of English and Education, 1(1), 89-95. https://ejournal.upi.edu/index.php/L-E/article/view/332

Hyland, K. (2002). Teaching and researching writing. Longman.

Luu, T. T. (2011). Teaching writing through genre-based approach. BELT - Brazilian English Language Teaching Journal, 2(1), 121-136. https://revistaseletronicas.pucrs.br/ojs/index.php/belt/article/view/9361

Refnaldi. (2013). The process-genre based model for teaching essay writing. In Proceeding of the International Seminar on Languages and Arts (vol. 2, pp. 479-485). FBS Universitas Negeri Padang. http://ejournal.unp. ac.id/index.php/isla/article/viewFile/4717/3687

Rusinovci, X. (2015). Teaching writing through process-genre based approach. US-China Education Review, 5(10), 699-705. http://doi.org/10.17265/2161-623X/2015.10.006

Saputra, H., \& Marzulina, L. (2015). Teaching writing by using process genre approach to the eighth grade students of SMP Negeri 22 Palembang. Edukasi: Jurnal Pendidikan Dan Pengajaran, 2(1), 1-12. http://jurnal. radenfatah.ac.id/index.php/edukasi/article/view/592

Savage, A., \& Mayer, P. (2012). Effective academic writing 2: The short essay ( $2^{\text {nd }}$ ed). Oxford University Press.

$\mathrm{Xu}, \mathrm{X}$., \& Li, X. (2018). Teaching academic writing through process-genre approach: A pedagogical exploration of an EAP program in China. TESL-EJ, 22(2), 1-21. http://www.tesl-ej.org/pdf/ej86/a1.pdf

Yuvaypan, F., \& Rathert, S. (2018). Teaching academic writing in ELT postgraduate programmes at Turkish Universities. International Journal of Language Academy, 6(2), 49- 64. http://dx.doi.org/10.18033/ijla

Zhang, Y. (2018). Exploring EFL learners' self-efficacy in academic writing based on process-genre approach. English Language Teaching, 11(6), 115-124. http://doi.org/10.5539/elt.v11n6p115 


\section{Appendix 1}

\section{Pretest}

Read the opinion in the chart below. Think of the arguments for and against this opinion and make notes in the Agree or Disagree columns (an example for each was given to you). Consider your arguments: do you agree or disagree with the opinion. Write a three-paragraph opinion essay depending on your agreement.

\begin{tabular}{ccc}
\hline \multicolumn{1}{c}{ Agree } & \multicolumn{1}{c}{ Opinion } & Disagree \\
\hline E.g. Good education & Living in big cities is better than living in the countryside. & E.g. the countryside has pure air and water \\
\hline
\end{tabular}

\section{Appendix 2}

\section{Posttest}

Read the opinion in the chart below. Think of the arguments for and against this opinion and make notes in the Agree or Disagree columns (an example for each was given to you). Consider your arguments: do you agree or disagree with the opinion. Write a three-paragraph opinion essay depending on your agreement.

\begin{tabular}{lll}
\hline \multicolumn{1}{c}{ Agree } & \multicolumn{1}{c}{ Opinion } & \multicolumn{1}{c}{ Disagree } \\
\hline $\begin{array}{l}\text { E.g. Students lose their study time using the } \\
\text { internet }\end{array}$ & $\begin{array}{l}\text { The internet has a negative influence on } \\
\text { students. }\end{array}$ & $\begin{array}{l}\text { E.g. Students use the internet in their } \\
\text { study }\end{array}$ \\
\hline
\end{tabular}

